\title{
Application of Fuzzy Logic in the Selection of a Suitable Sanitary Landfill Site for Solid Waste Disposal and Management in Coastal Area of Nigeria
}

\author{
${ }^{1}$ Audu, H.A.P, ${ }^{2}$ Iyeke, S.D and ${ }^{3}$ Aladenika, A \\ ${ }^{1,2,3}$ Department of Civil Engineering, Faculty of Engineering, University of Benin, P.M.B 1154, Benin City, Edo \\ State, Nigeria
}

\begin{abstract}
Solid waste management has been identified as one of the most challenging environmental problems facing cities in most developing countries because of the risks to human health and the general environment. Different methods are available for solid waste disposal and they include; ocean dumping open burning and sanitary landfill. Of these available methods, sanitary landfill remains the most effective and hygienic method of solid waste disposal. Inspite of its effectiveness, the method of waste disposal using sanitary landfill is challenged by the availability of suitable land. To select a suitable site for landfill application numerous factors must be considered, ranging from; flood extent, stream, rivers, swampy areas, ground water, built-up areas, roads, slopes, airport, palaces and point of interests (POIs). In this study, fuzzy logic technique of data analysis was employed to analyze the various factors in order to select the most suitable site for landfill application in the study area. The basic steps involved in the application of fuzzy logic in the modeling and prediction of suitable site for landfill application are as follows; definition of input and output variables, conversion of crisp variables into fuzzy sets, definition of membership functions for each inputs and output variables, creation of fuzzy rules and simulation. Result of the fuzzy simulation revealed that; for river buffer distance of $0.9909 \mathrm{~km}$, ground water elevation of $7.13 \mathrm{~m}$, road buffer distance of $0.7727 \mathrm{~km}$, land slope of $2.673^{\circ}$ and built-up area buffer distance of $1.37 \mathrm{~km}$, suitability ranking is 2 which mean "least suitable. For river buffer distance of $1.355 \mathrm{~km}$, ground water elevation of $9.537 \mathrm{~m}$, road buffer distance of $1.645 \mathrm{~km}$, land slope of $3.655^{\circ}$ and built-up area buffer distance of $1.778 \mathrm{~km}$, suitability ranking is 3 which means "moderately suitable" and for river buffer distance of $2.5 \mathrm{~km}$, ground water elevation of $15 \mathrm{~m}$, road buffer distance of $2.5 \mathrm{~km}$, land slope of $6^{0}$ and built-up area buffer distance of $2.5 \mathrm{~km}$, suitability ranking is 4 which means "highly suitable"
\end{abstract}

Keywords: Sanitary landfill, Fuzzy logic, Membership functions, Fuzzy rules and Suitability rating

DOI: $10.7176 / \mathrm{JEES} / 10-1-07$

Publication date: January $31^{\text {st }} 2020$

\section{Introduction}

Proper management of solid waste is critical to the health and well-being of urban resident (World Bank, 2013). Nigerians had been concerned with solid waste disposal; but their concern had not gone beyond physical removal of waste from the street. It has been a common practice to dispose solid wastes using open dump or the use of an open burning. There is need for these wastes to be properly and safely disposed to minimize environment damage. Associated with management of waste is the sitting of waste disposal facilities which is the central issue in waste management (Nas et al., 2008). These facilities are landfills, waste and sewage treatment plants and incinerators among others. However, landfill has been recommended as the best facilities for handling waste in developing countries (Egun, 2011, Moeinaddini et al., 2010, Guiqin et al., 2009). Appropriate site selection for waste disposal is one of the major problems in waste management (Davidson, 2011). Selection of suitable site for landfill application can be extremely complex mainly due to the fact that the selection process involves many factors, criteria and regulations. The landfill site selection depends on large volume of spatial data to be evaluated, analyzed and processed. The use of novel tools and technologies to gain a suitable site for landfill seems imperative (Sha'A to et al., 2007). AHP as developed by Saaty, (2008) is one of the GIS based Multi Criteria Decision Maker (MCDM) that combines and transforms spatial data into a resultant decision in a structured and transparent way. The procedure involves the utilization of geographical data, the manipulation of data according to the decision maker's preferences and specified decision rules, referred to as factors and constrains. Although AHP remains an effective method for the selection of a suitable landfill site, the unavailability of spatial data in some remote areas tends to limits its application and wider acceptability hence, the need for data analysis techniques such as fuzzy logic.

Fuzzy logic has become an important tool for number of different applications ranging from the control of engineering system to artificial intelligence. Practical applications of fuzzy logic pose a unique set of problems. The design of systems, which apply fuzzy logic to make use of human knowledge and experience, is a daunting task without facing engineering problems of real-world systems (Unahabhokha et al., 2007). Fuzzy logic is a form of many-valued logic; it deals with reasoning that is approximate rather than fixed and exact. Compared to traditional binary sets (where variables may take on true or false values), fuzzy logic variables may have a truth 
value that ranges in degree between 0 and 1 . Fuzzy logic is based on the theory of fuzzy sets, which is a generalization of the classical set theory. Saying that the theory of fuzzy sets is a generalization of the classical set theory means that the latter is a special case of fuzzy sets theory (Zadeh, 2016). A fuzzy set is a set without a crisp, not clearly defined boundary. It can contain elements with a partial degree of membership with multi-valued logic. Fuzzification comprises the process of transforming discrete values into grades of membership (continuous) for linguistic terms of fuzzy sets. Degree of membership is a specific value that defines how each point in the input space is mapped to the specific environment being studied lying between 0 and 1. Linguistic Variable means relating to language, (plain language words and statements). While variables in mathematics usually take numerical values, in fuzzy logic, the non-numeric linguistic variables are often used to facilitate the expression of rules and facts (Sirigiri et al., 2012, Akbari et al., 2008, Gernitzi et al., 2007).

\section{Research Methodology}

\subsection{Description of Study Area}

The study area is Warri in Delta state. Warri is one of the most important towns in Delta state, located in the SouthSouth geo-political zone of Niger Delta Region of Nigeria. Warri is located within latitudes $5^{0} 28^{\prime} 10.79^{\prime \prime} \mathrm{N}$ to $5^{0}$ $37^{\prime} 27.99^{\prime \prime} \mathrm{N}$ and longitudes $5^{0} 40^{\prime} 32.78^{\prime \prime} \mathrm{E}$ to $5^{0} 51^{\prime} 51.47^{\prime \prime} \mathrm{E}$ which is $399.809 \mathrm{~km}^{2}$ by area. It is situated $48 \mathrm{~km}$ upstream from the port of Forcados and at the terminus of road from Sapele and Ughelli. It has a navigable channel of water front of about 61meters. As a major industrial city in Delta state, on the Niger-Delta region bounded by Warri North LGA in the northern part of the state, in the west by Warri southwest LGA, in the east by Sapele LGA while in the south by Burutu LGA. There are creeks in the area such as Tori creek, Warri creek, and the major river. Warri is characterized by two major seasons namely, the rainy (wet) season and the dry season. The rainy season lasts from April to October which is a period of seven months. There is however a break in the rainy season by August after which it resumes and the rainfall becomes stronger. The dry season (harmattan) is short and starts from November to March. The effect of the short period of harmattan is minor and heavy down pour seldom occurs in the heart of the dry season. Warri experiences high annual rainfall of over $3,000 \mathrm{~mm}$, which is distributed throughout the year. The temperature is uniformly high with an annual means of $30^{\circ} \mathrm{C}$ and very low daily range of $28^{\circ} \mathrm{C}$ with relative humidity as high as $85 \%$. The population of Warri has increased over the years. Warri metropolis is one of the rapidly growing cities in Nigeria with a population rising rapidly from 55,256 in 1963, 280,561 in 1980, and 511,074 in 1991 to 632,243 in 2006 and estimated to be 930,000 in 2016 (Tajuddin, 2003). The satellite imagery of Warri, Delta State is shown in Figure 1

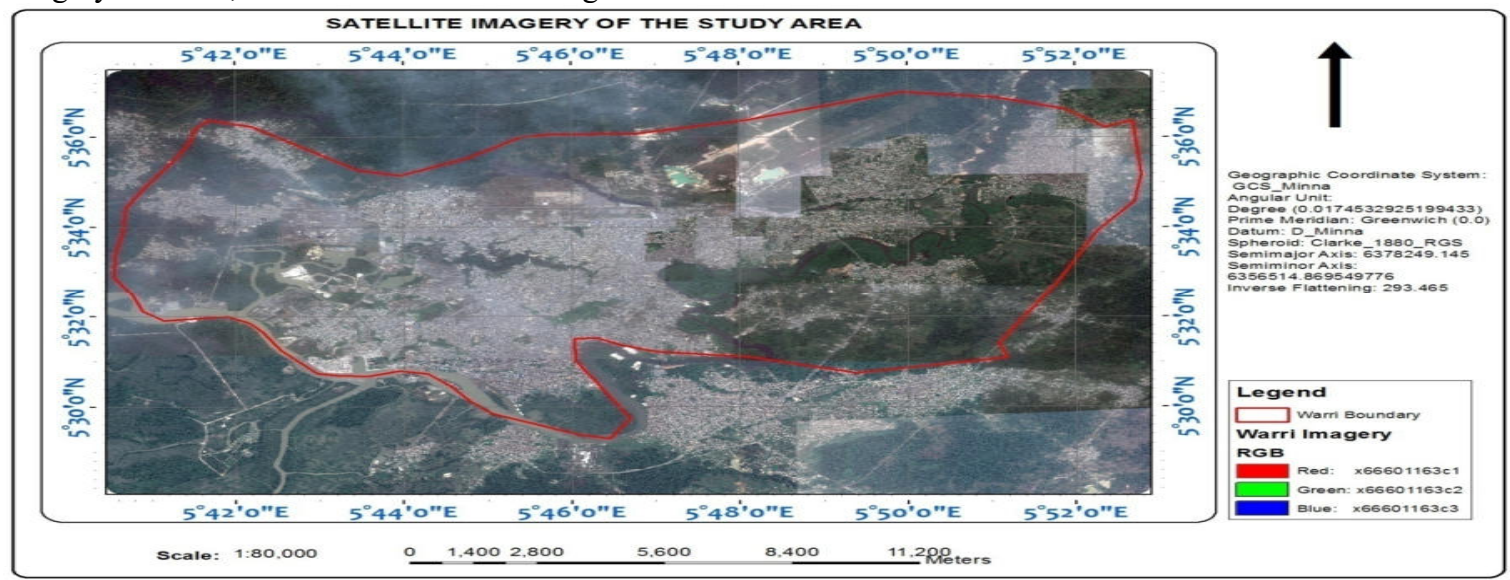

Figure 1: Satellite imagery of Warri, Delta State (Adopted from Google Earth)

\subsection{Criteria for landfill site selection}

A set of criteria was developed by combining an intensive literature review and expert knowledge. Some criteria such as flood extent, stream, rivers, swampy areas, ground water, built-up areas, roads, slopes, airport, palaces and point of interests (POIs) were identified for the study area. Features of interest such as roads, built-up areas, swampy areas, rivers and streams in the SPOT 5 satellite imagery were converted to vector format by digitizing in order to create a geographic database dataset. All the datasets used for this work were projected to Universal Transverse Mercator Zone 31N in WGS 1984 datum. The study adopted Weighted Overlay Linear Combination. The decision-making process criteria used for this work are constraints and factors. Constraints were used to eliminate certain spatial objects from consideration. Factors were criteria which were grouped into themes. Suitability rating is a scale that assesses the suitability of parcel of land for a particular purpose. The suitability rating is dependent on the constraint. Suitability rating value of 1 to 5 was adopted in this study; value 1 means 
not suitable, 2 means least suitable, 3 means moderately suitable, 4 means highly suitable and 5 means mostly suitable. The work flow for this work is presented in Figure 2

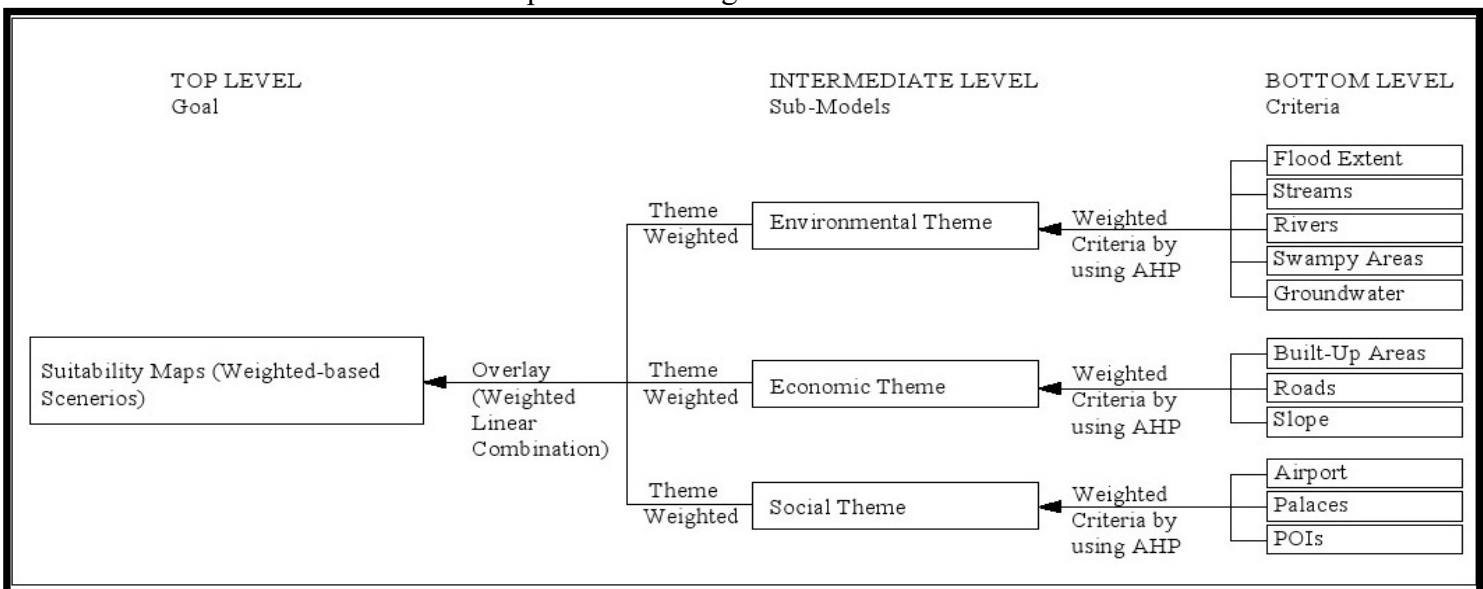

Figure 2: Workflow of the study

\subsection{Fuzzy logic modeling}

To determine crisp variables used in the fuzzy logic systems, the formula were adopted from Chang et al., 2008 as follows;

$$
\mathrm{A}=\left(a_{i j}\right)_{n x n}=\left[\begin{array}{cccc}
(1,1,1) & \left(l_{12}, m_{12}, u_{12}\right) & \ldots \ldots \ldots . . . & \left(l_{1 n}, m_{1 n}, u_{1 n}\right) \\
\left(l_{21}, m_{21}, u_{12}\right) & (1,1,1) & \ldots \ldots \ldots . . & \left(l_{2 n}, m_{2 n}, u_{2 n}\right) \\
\vdots & \vdots & \vdots & \vdots \\
\left(l_{n 1}, m_{n 1}, u_{n 1}\right) & l_{n 2}, m_{n 2}, u_{n 2} & \ldots \ldots \ldots \ldots & (1,1,1)
\end{array}\right]
$$

Where $a_{i j}=\left(l_{i j}, m_{i j}, u_{i j}\right)=a i j=\left(1 / u_{j i}, \quad 1 / m_{j i} 1 / l_{j i}\right)$ for $\mathrm{I}, \mathrm{j}=1--------, \mathrm{n}$ and $\mathrm{I} \neq \mathrm{j}$.

To calculate a priority vector of the above triangular fuzzy comparison matrix, the following five equations were used: First, a fuzzy comparison operation was employed to sum up each row of the fuzzy comparison matrix

$$
R S_{i}=\sum_{j=1}^{n} a_{i j}=\left(\sum_{j=1}^{n} l_{i j}, \sum_{j=1}^{n} m_{i j}, \sum_{j=1}^{n} u_{i j}\right), \quad \mathrm{i}=1 \ldots \mathrm{n}
$$

Secondly, the row sums were normalized using

$$
S_{i}=\frac{R S_{i}}{\sum_{j=1}^{n} R S_{j}}=\left(\frac{\sum_{j=1}^{n} l_{i j}}{\sum_{j=1}^{n} l_{i j}+\sum_{k=1, k \neq i}^{n}+\sum_{j=1}^{n} u_{k j}}, \frac{\sum_{j=1}^{n} m_{i j}}{\sum_{k=1}^{n} \sum_{j=1}^{n} m_{k j}}, \frac{\sum_{j=1}^{n} u_{i j}}{\sum_{j=1}^{n} u i_{j}+\sum_{k=1, k \neq i}^{n} 1 \sum_{j=1}^{n} l_{k j}}\right), \mathrm{i}=1 \ldots \mathrm{n}
$$

Thirdly, the degree of possibility of $S_{i} \leq S_{j}$ was computed with the aid of equation (4)

$V(S i \geq S j)=\left\{\begin{array}{ccc}1 & m i \geq m j & 1 \\ \frac{u i-l j}{(u i-m i)(m j-l j)}, & l j \leq u j & 1 \\ 0 & \text { others } & 1\end{array}\right\} \quad \mathrm{I}, \mathrm{j}=1 \ldots \mathrm{n}, \mathrm{j} \neq i$

Where the possibility degree is $S_{i}=\left(l_{i}, m_{i}, u_{i}\right)$ and $S_{j}=\left(l_{j}, m_{j}, u_{j}\right)$ 
Fourthly, the degree of possibility of $S_{i}$ over all the other $(\mathrm{n}-1)$ fuzzy member was computed by:

$V\left(S_{i} \geq S_{j} j=1 \ldots \ldots, n ; j \neq i\right)=V\left(S_{i} \geq S_{j}\right), i=1, \ldots \ldots . ., n$

Finally, the priority vector $W=\left(w_{1} \ldots \ldots \ldots, w_{n}\right)^{T}$ of the fuzzy comparison matrix A was defined as

$$
w i=\frac{V\left(S_{i} \geq S_{j} j=1, \ldots \ldots \ldots, n ; j \neq i\right)}{\sum_{k=1}^{n} V\left(S_{k} \geq S_{j} j=1, \ldots \ldots \ldots ., n ; j \neq k\right)}, \quad \mathrm{i}=1 \ldots \mathrm{n}
$$

The basic steps involved in the application of fuzzy logic in the modelling and prediction of suitable site for landfill application are as follows;

i. Definition of input and output variables

ii. Conversion of crisp variables into fuzzy sets

iii. Definition of membership functions for each inputs and output

iv. Creation of fuzzy rules

v. Simulation

\subsubsection{Definition of input and output variables}

i. First, sets of environmental, economic and social themes were selected

ii. The sets of themes were then reduced to the five critical inputs requirements for a fuzzy logic modelling. The criteria for this selection are based on review of relevant literatures and the numbers of input parameters that can be accommodated in a fuzzy logic toolbox

iii. The relative importance of the selected variables was then evaluated based on the fundamental concept of the study

For a model that is aimed at predicting the optimum site for landfill location based on some selected criteria, we assumed that; flood extent buffer distance (FEBD), river buffer distance (RIBD), stream buffer distance (SBD), swampy area buffer distance (SABD), ground water elevation (GWE), road buffer distance (RBD), land slope (LS), built up area buffer distance (BUABD), airport buffer distance (ABD), palace buffer distance (PBD) and POIs buffer distance (POIsBD) be the linguistic variables which represents the environmental theme, economic theme and social theme. To qualify the flood extent buffer distance (FEBD), river buffer distance (RBD), stream buffer distance (SBD), swampy area buffer distance (SABD), ground water elevation (GWE), road buffer distance (RBD), land slope (LS), built up area buffer distance (BUABD), airport buffer distance (ABD), palace buffer distance (PBD) and POIs buffer distance (POIsBD), terms such as (very low, low, moderately high, high and very high) were used. These are the linguistic values of the flood extent buffer distance (FEBD), river buffer distance (RBD), stream buffer distance (SBD), swampy area buffer distance (SABD), ground water elevation (GWE), road buffer distance (RBD), land slope (LS), built up area buffer distance (BUABD), airport buffer distance (ABD), palace buffer distance (PBD) and POIs buffer distance (POIsBD). Then,

FEBD $($ febd $)=\{$ very low, low, moderate high, high, very high $\}$

RIBD $($ ribd $)=\{$ very low, low, moderate high, high, very high $\}$

$\mathrm{SBD}(\mathrm{sbd})=\{$ very low, low, moderate high, high, very high $\}$

$\operatorname{SABD}(\mathrm{sabd})=\{$ very low, low, moderate high, high, very high $\}$

GWE $($ gwbd $)=\{$ very low, low, moderate high, high, very high $\}$

$\mathrm{RBD}(\mathrm{rbd})=\{$ very low, low, moderate high, high, very high $\}$

LS $(1 \mathrm{~s})=$ \{very low, low, moderate high, high, very high $\}$

$\mathrm{BUABD}($ buabd $)=\{$ very low, low, moderate high, high, very high $\}$

$\mathrm{ABD}(\mathrm{abd})=$ very low, low, moderate high, high, very high $\}$

$\mathrm{PBD}(\mathrm{pbd})=\{$ very low, low, moderate high, high, very high $\}$

POIsBD $($ poisbd $)=$ \{very low, low, moderate high, high, very high $\}$

In the same way, the output variable; suitability rating (SR) was define in real term as:

$\mathrm{SR}(\mathrm{sr})=\{\mathrm{NS}, \mathrm{LS}, \mathrm{MS}, \mathrm{HS}, \mathrm{MOS}\}=\{1,2,3,4,5\}$

The terms in bracket represent the set of decompositions for the linguistic variables; flood extent buffer distance (FEBD), river buffer distance (RIBD), stream buffer distance (SBD), swampy area buffer distance (SABD), ground water elevation (GWE), road buffer distance (RBD), land slope (LS), built up area buffer distance (BUABD), airport buffer distance (ABD), palace buffer distance (PBD) and POIs buffer distance (POIsBD). Each member of this decomposition is called a linguistic term. For this problem, the linguistic variables and their range 
of values include:

i. Flood extent buffer distance (FEBD); this range from 0.5 to $2.5 \mathrm{~km}$

ii. River buffer distance (RIBD); this range from 0.5 to $2.5 \mathrm{~km}$

iii. Stream buffer distance (SBD); this range from 0.5 to $2.5 \mathrm{~km}$

iv. Swampy area buffer distance (SABD); this range from 0.5 to $2.5 \mathrm{~km}$

v. Ground water elevation (GWE); this range from 5 to $15 \mathrm{~m}$

vi. Road buffer distance (RBD); this range from 0.5 to $2.5 \mathrm{~km}$

vii. Land slope (LS); this range from 0 to $6^{0}$

viii. Built up area buffer distance (BUABD); this range from 0.5 to $2.5 \mathrm{~km}$

ix. Airport buffer distance (ABD); this range from 0.5 to $15 \mathrm{~km}$

$\mathrm{x}$. Palace buffer distance (PBD); this range from 0.5 to $2.5 \mathrm{~km}$

xi. POIs buffer distance (POIsBD); this range from 0.5 to $2.5 \mathrm{~km}$

xii. Suitability Rating (SR); this range from 1 to 5

Based on the range and values of each linguistic variable, an overall input table was formulated as presented in Table 1

Table 1: Input parameters for fuzzy logic modeling

\begin{tabular}{|c|c|c|c|c|c|c|}
\hline \multirow{2}{*}{ S/No } & Landfill Selection Criteria's & \multicolumn{4}{c|}{ Suitability Assessment Code for Input Values } \\
\cline { 3 - 7 } & NS & LS & MS & HS & MOS \\
\hline 1 & Flood Extent Buffer Distance $(\mathrm{km})$ & $0.5(\mathrm{VL})$ & $1.0(\mathrm{~L})$ & $1.5(\mathrm{MH})$ & $2.0(\mathrm{H})$ & $2.5(\mathrm{VH})$ \\
\hline 2 & River Buffer Distance $(\mathrm{km})$ & $0.5(\mathrm{VL})$ & $1.0(\mathrm{~L})$ & $1.5(\mathrm{MH})$ & $2.0(\mathrm{H})$ & $2.5(\mathrm{VH})$ \\
\hline 3 & Stream Buffer Distance $(\mathrm{km})$ & $0.5(\mathrm{VL})$ & $1.0(\mathrm{~L})$ & $1.5(\mathrm{MH})$ & $2.0(\mathrm{H})$ & $2.5(\mathrm{VH})$ \\
\hline 4 & Swampy Area Buffer Distance $(\mathrm{km})$ & $0.5(\mathrm{VL})$ & $1.0(\mathrm{~L})$ & $1.5(\mathrm{MH})$ & $2.0(\mathrm{H})$ & $2.5(\mathrm{VH})$ \\
\hline 5 & Ground Water Elevation $(\mathrm{m})$ & $5.0(\mathrm{VL})$ & $9.5(\mathrm{~L})$ & $11.8(\mathrm{MH})$ & $13.8(\mathrm{H})$ & $15(\mathrm{VH})$ \\
\hline 6 & Road Buffer Distance $(\mathrm{km})$ & $0.5(\mathrm{VL})$ & $1.0(\mathrm{~L})$ & $1.5(\mathrm{MH})$ & $2.0(\mathrm{H})$ & $2.5(\mathrm{VH})$ \\
\hline 7 & Land Slope (degree) & $0(\mathrm{VL})$ & $1.0(\mathrm{~L})$ & $2.0(\mathrm{MH})$ & $3.0(\mathrm{H})$ & $6.0(\mathrm{VH})$ \\
\hline 8 & Built-up Areas Buffer Distance $(\mathrm{km})$ & $0.5(\mathrm{VL})$ & $1.0(\mathrm{~L})$ & $1.5(\mathrm{MH})$ & $2.0(\mathrm{H})$ & $2.5(\mathrm{VH})$ \\
\hline 9 & Airport Buffer Distance $(\mathrm{km})$ & $3.0(\mathrm{VL})$ & $6.0(\mathrm{~L})$ & $9.0(\mathrm{MH})$ & $12.0(\mathrm{H})$ & $15.0(\mathrm{VH})$ \\
\hline 10 & Palace Buffer Distance $(\mathrm{km})$ & $0.5(\mathrm{VL})$ & $1.0(\mathrm{~L})$ & $1.5(\mathrm{MH})$ & $2.0(\mathrm{H})$ & $2.5(\mathrm{VH})$ \\
\hline 11 & POIs Buffer Distance $(\mathrm{km})$ & $0.5(\mathrm{VL})$ & $1.0(\mathrm{~L})$ & $1.5(\mathrm{MH})$ & $2.0(\mathrm{H})$ & $2.5(\mathrm{VH})$ \\
\hline 12 & Suitability Ranking & NS $\mathbf{1}$ & $\mathbf{L S}=\mathbf{2}$ & $\mathbf{M S}=\mathbf{3}$ & $\mathbf{H S}=\mathbf{4}$ & $\mathbf{M O S}=\mathbf{5}$ \\
\hline
\end{tabular}

VL = Very Low; L = Low; MH = Moderately High; H = High; VH = Very High

NS $=$ Not Suitable, LS $=$ Less Suitable, MS $=$ Moderately Suitable, HS $=$ Highly Suitable, MOS $=$ Most Suitable

2.3.2 Selection of critical input variables

The numbers of input variables that can be accommodated in a fuzzy logic system informed the decision to reduce the initial numbers of input variables presented in Table 1. Based on the review of some literatures on the critical factors that influence landfill site selection, five out of the eleven initial criteria were selected as presented in Table 2. The fuzzy logic toolbox showing the input variables and the output variable is presented in Figure 3.

Table 2: Critical input parameters selected for fuzzy logic modeling

\begin{tabular}{|c|c|c|c|c|c|c|}
\hline \multirow{2}{*}{ S/No } & $\begin{array}{c}\text { Landfill Selection } \\
\text { Criteria's }\end{array}$ & $\begin{array}{c}\text { Suitability Assessment } \\
\text { Code for Input Values }\end{array}$ & \multicolumn{4}{|l|}{} \\
\cline { 3 - 7 } & & NS & LS & MS & HS & MOS \\
\hline 1 & River Buffer Distance $(\mathrm{km})$ & $0.5(\mathrm{VL})$ & $1.0(\mathrm{~L})$ & $1.5(\mathrm{MH})$ & $2.0(\mathrm{H})$ & $2.5(\mathrm{VH})$ \\
\hline 2 & Ground Water Elevation $(\mathrm{m})$ & $5.0(\mathrm{VL})$ & $9.5(\mathrm{~L})$ & $11.8(\mathrm{MH})$ & $13.8(\mathrm{H})$ & $15(\mathrm{VH})$ \\
\hline 3 & Road Buffer Distance $(\mathrm{km})$ & $0.5(\mathrm{VL})$ & $1.0(\mathrm{~L})$ & $1.5(\mathrm{MH})$ & $2.0(\mathrm{H})$ & $2.5(\mathrm{VH})$ \\
\hline 4 & Land Slope (degree) & $0(\mathrm{VL})$ & $1.0(\mathrm{~L})$ & $2.0(\mathrm{MH})$ & $3.0(\mathrm{H})$ & $6.0(\mathrm{VH})$ \\
\hline 5 & Built-up Areas Buffer $(\mathrm{km})$ & $0.5(\mathrm{VL})$ & $1.0(\mathrm{~L})$ & $1.5(\mathrm{MH})$ & $2.0(\mathrm{H})$ & $2.5(\mathrm{VH})$ \\
\hline 6 & Suitability Ranking & $\mathbf{N S}=\mathbf{1}$ & $\mathbf{L S}=\mathbf{2}$ & $\mathbf{M S}=\mathbf{3}$ & $\mathbf{H S}=\mathbf{4}$ & $\mathbf{M O S}=\mathbf{5}$ \\
\hline
\end{tabular}




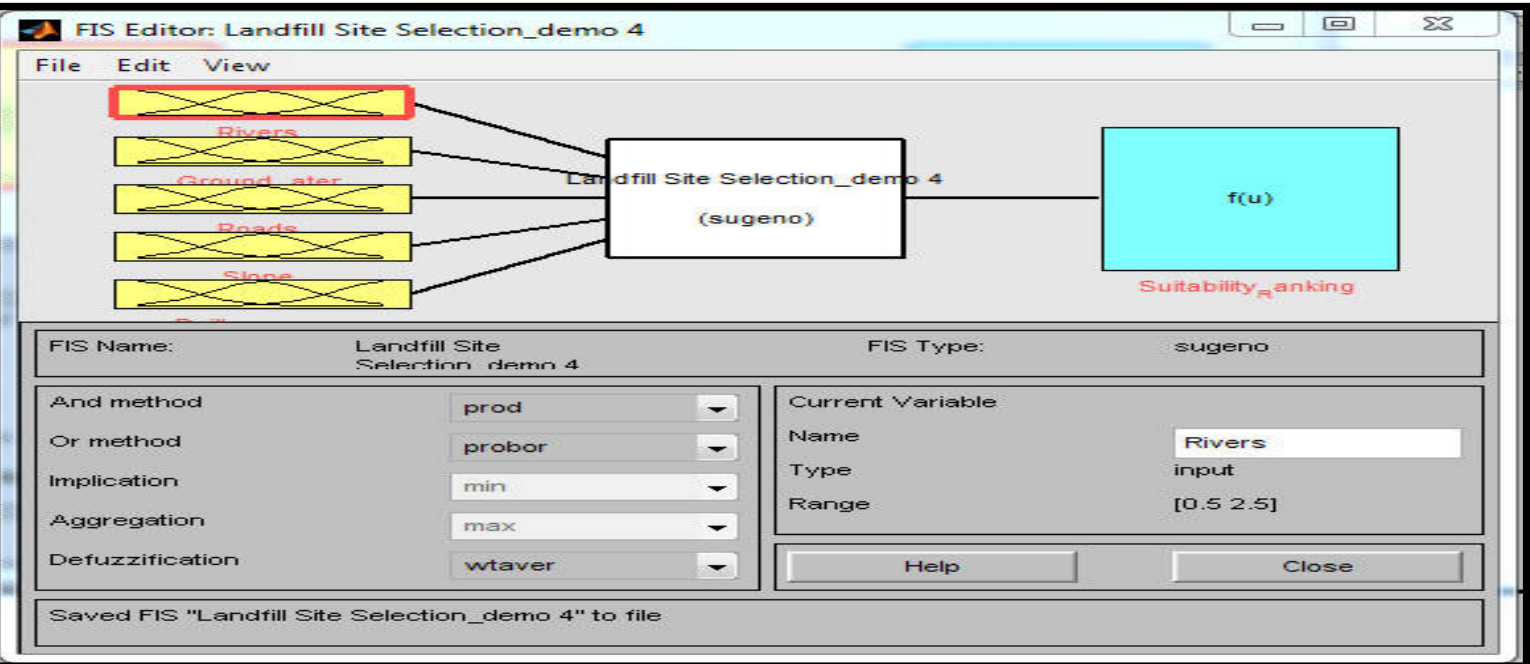

Figure 3: Defining the input and output variables in a fuzzy logic system

\subsubsection{Conversion of crisp variables to fuzzy sets}

To convert the crisp variables to fuzzy sets, adaptive neuro-fuzzy inference systems (ANFIS) was employed. The basic steps in the application of ANFIS are as follows:

i. The five critical input variables were coded using a, b, c, d, e, f

ii. The members of the variables were also defined

iii. A simple MATLAB programmer that connects the input and output variables was then written

To generate the fuzzy inference system (FIS), grid partition method was employed owing to its ability to handle large input variables and generate the needed fuzzy sets.

\subsubsection{Definition of membership function}

i. Five membership function were selected for each input variables and output variables, namely; very low, low, moderately high, high and very high

ii. For the input variables, the triangular membership function (trimf) was used while the constant membership function was used for the output variable

\subsubsection{Creation of fuzzy rules}

For this study, eight rules were created for fuzzy logic simulation. The rules are defined as follows:

i. If the buffer distance for river is very low and the ground water elevation is very low and the buffer distance for road is very low and the slope of the land is very low and the buffer distance for built-up areas is very low, then the suitability ranking is "not suitable"

ii. If the buffer distance for river is low and the ground water elevation is low and the buffer distance for road is low and the slope of the land is low and the buffer distance for built-up areas is low, then the suitability ranking is "least suitable"

iii. If the buffer distance for river is moderately high and the ground water elevation is moderately high and the buffer distance for road is moderately high and the slope of the land is moderately high and the buffer distance for built-up areas is moderately high, then the suitability ranking is "moderately suitable"

iv. If the buffer distance for river is high and the ground water elevation is high and the buffer distance for road is high and the slope of the land is high and the buffer distance for built-up areas is high, then the suitability ranking is "highly suitable"

v. If the buffer distance for river is very high and the ground water elevation is very high and the buffer distance for road is very high and the slope of the land is very high and the buffer distance for built-up areas is very high, then the suitability ranking is most "highly suitable"

vi. If the buffer distance for river is very low and the ground water elevation is very low and the buffer distance for road is low and the slope of the land is very low and the buffer distance for built-up areas is moderately high, then the suitability ranking is "not suitable"

vii. If the buffer distance for river is very high and the ground water elevation is very high and the buffer distance for road is very high and the slope of the land is very high and the buffer distance for built-up areas is moderately high, then the suitability ranking "highly suitable"

viii. If the buffer distance for river is high and the ground water elevation is high and the buffer distance for road is high and the slope of the land is moderately high and the buffer distance for built-up areas is moderately high, then the suitability ranking is "moderately suitable" 


\subsubsection{Fuzzy logic simulation}

Based on the rules, series of simulation were done to evaluate the capacity of fuzzy logic in predicting the suitability of a specific site for use in landfill applications.

\section{Results and Discussion}

\subsection{Generation of fuzzy sets from the crisp variables}

Figure 4 shows the interface of adaptive neuro fuzzy (anfis) containing the fuzzy sets for the six input variables, namely; river, swampy areas, ground water elevation, roads, land slope and built-up areas including the single output variable which is the suitability ranking.

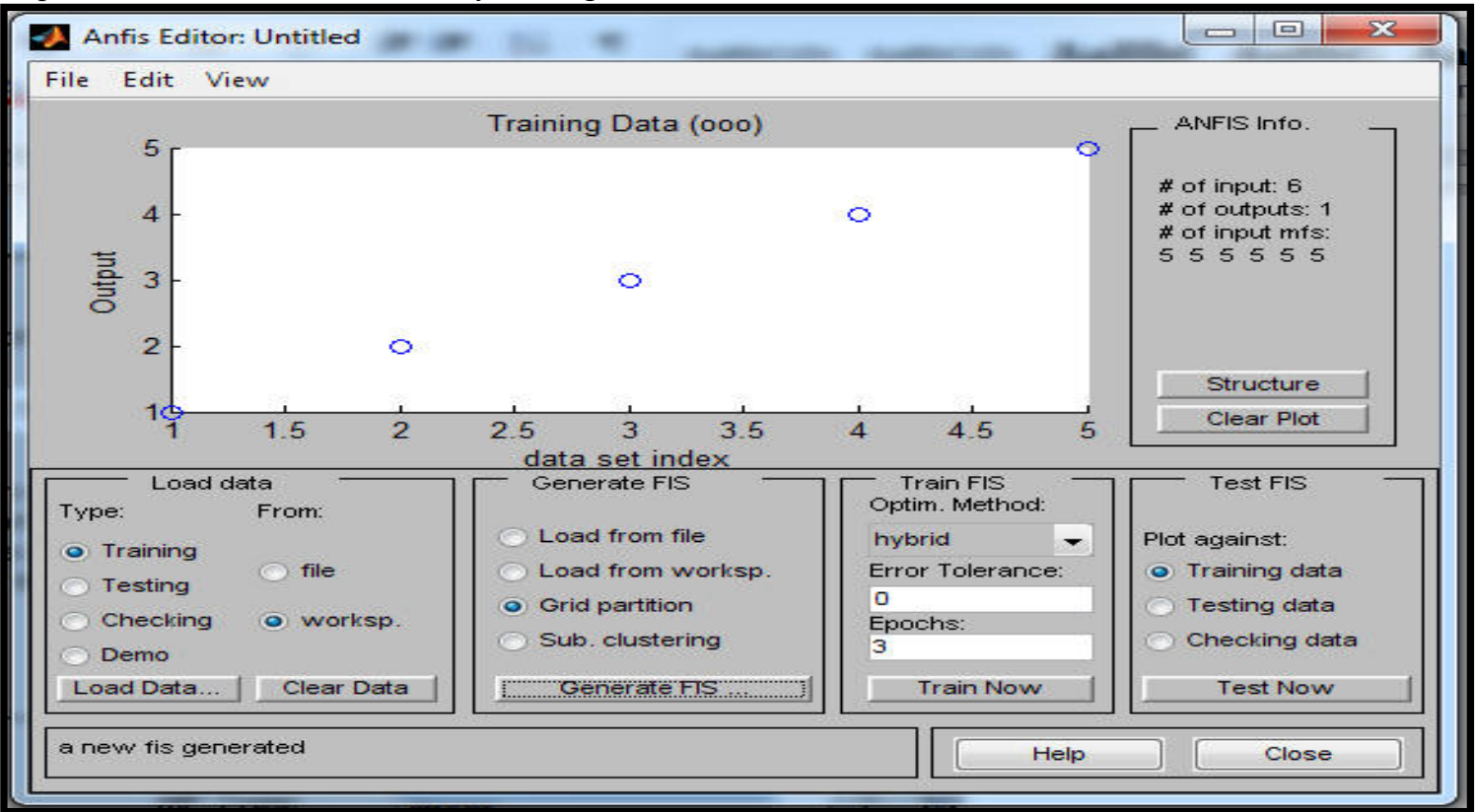

Figure 4: Anfisedit tool box showing the crisp data

Five membership functions were selected for each input variable. For this problem, the triangular membership function (trimf) was used. The simplicity and flexibility of the triangular membership function coupled with its ability to define wider range of decomposed sets of linguistic variables account for its selection. For the output variable, five membership functions were also used. Unlike the input variables, the constant membership function (conmf) was used to define the output variable owing to its simplicity. Figure 5 shows the membership function defined for the input and output variables. 


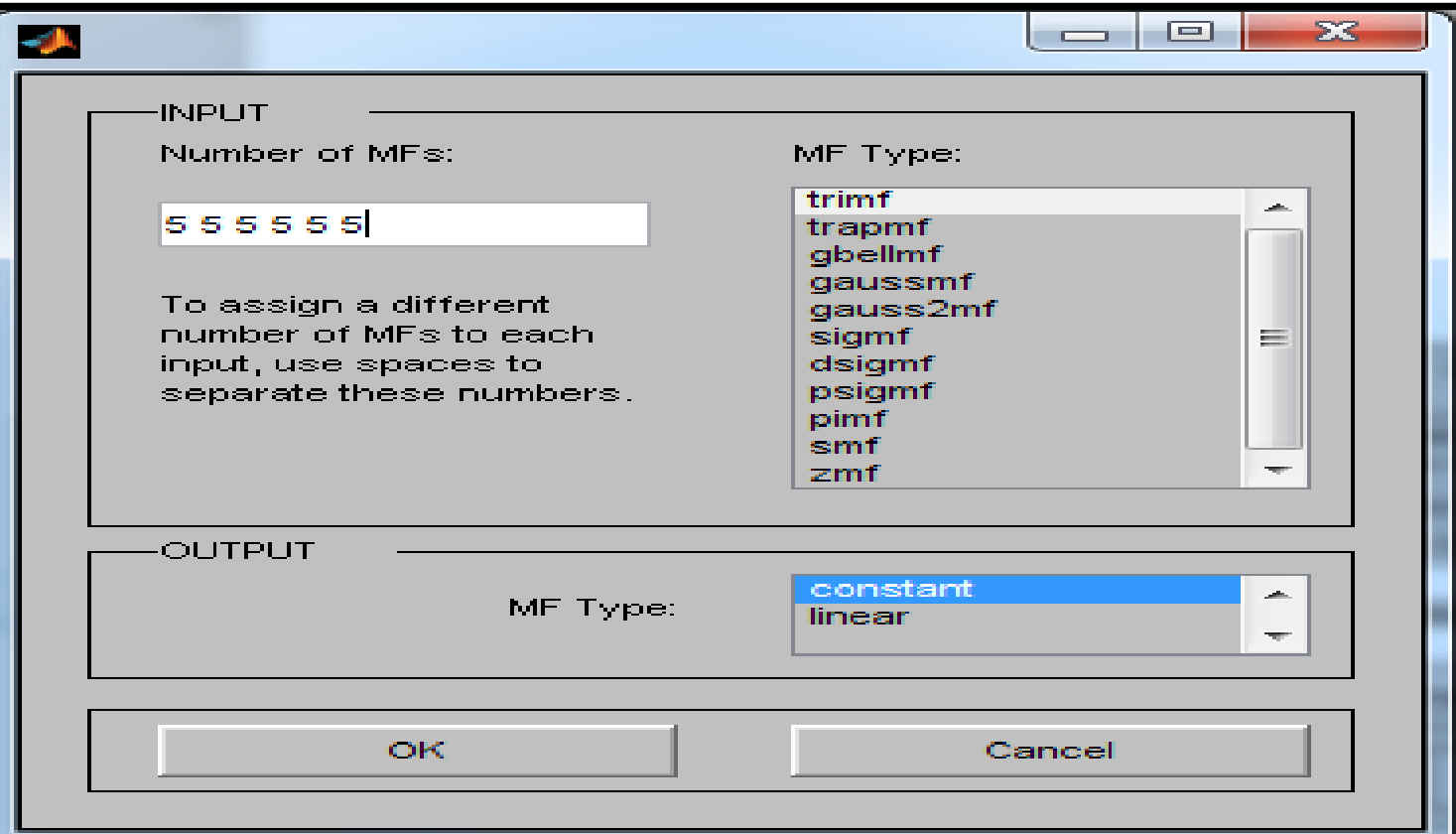

Figure 5: Description of input and output membership function

\subsection{Defining the inputs and output Membership Function}

Membership functions are used in the fuzzification and defuzzification steps of a Fuzzy Logic Systems (FLS), to map the non-fuzzy input values to fuzzy linguistic terms and vice versa. A membership function is used in most cases to quantify a linguistic term. An important characteristic of fuzzy logic is that a numerical value does not have to be fuzzified using only one membership function. In other words, a value can belong to multiple sets at the same time. Five membership functions were selected for each input and output variable namely; very low, low, moderately high, high and very high. Figures $6 \mathrm{a}, 6 \mathrm{~b}, 6 \mathrm{c}, 6 \mathrm{~d}, 6 \mathrm{e}$ and $6 \mathrm{f}$ shows the definition of the membership function for river, groundwater elevation, roads, slope, built-up areas and suitability ranking which is the five input criteria's and one output variable

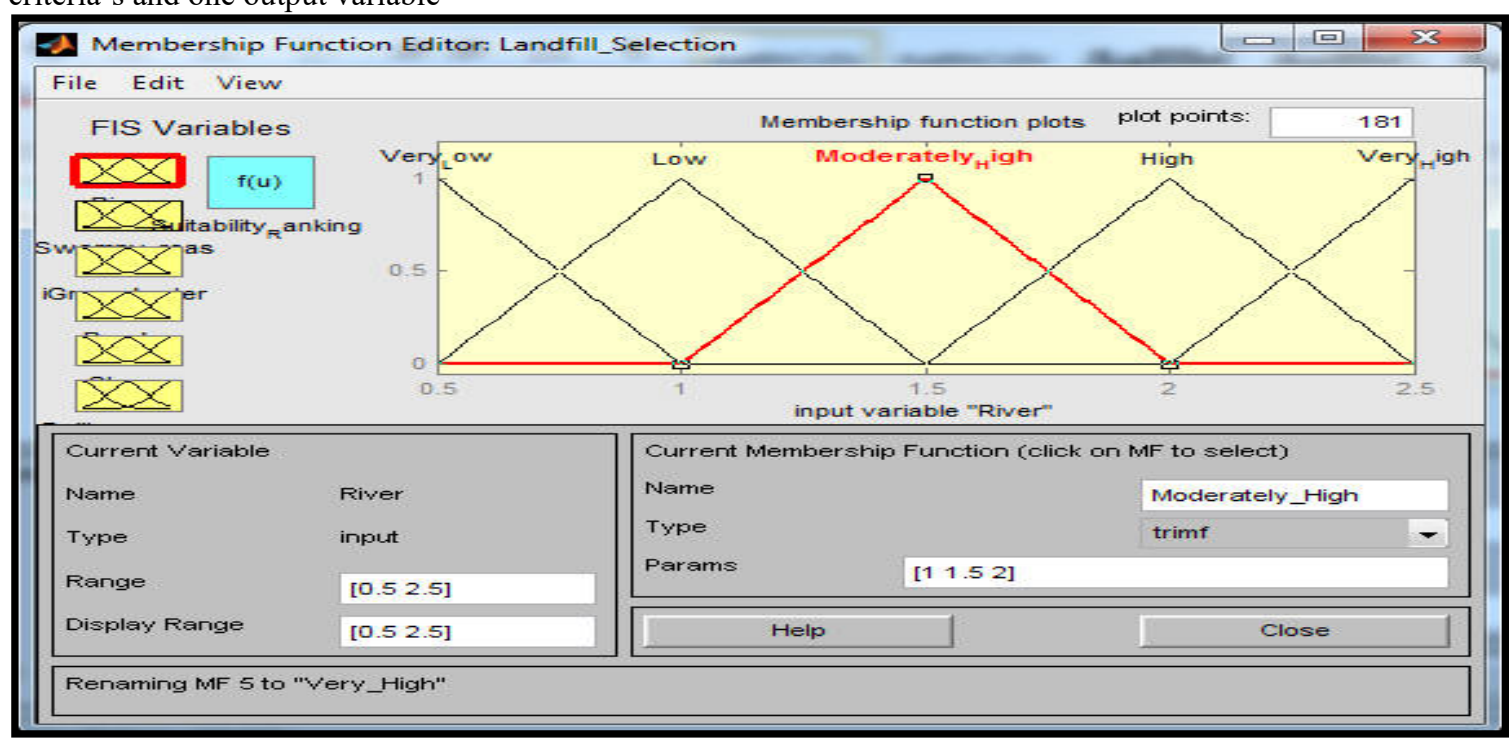

Figure 6a: Definition of membership function for River (moderately high buffer distance)

Figure 6a shows the membership function for river. The range for river buffer distance is specified as $[0.5$ to $2.5 \mathrm{~km}]$ while the membership set that defines moderately high buffer distance for river is given as $[1 \mathrm{~km}, 1.5 \mathrm{~km}$, $2 \mathrm{~km}]$. The membership function type is the triangular membership function. 


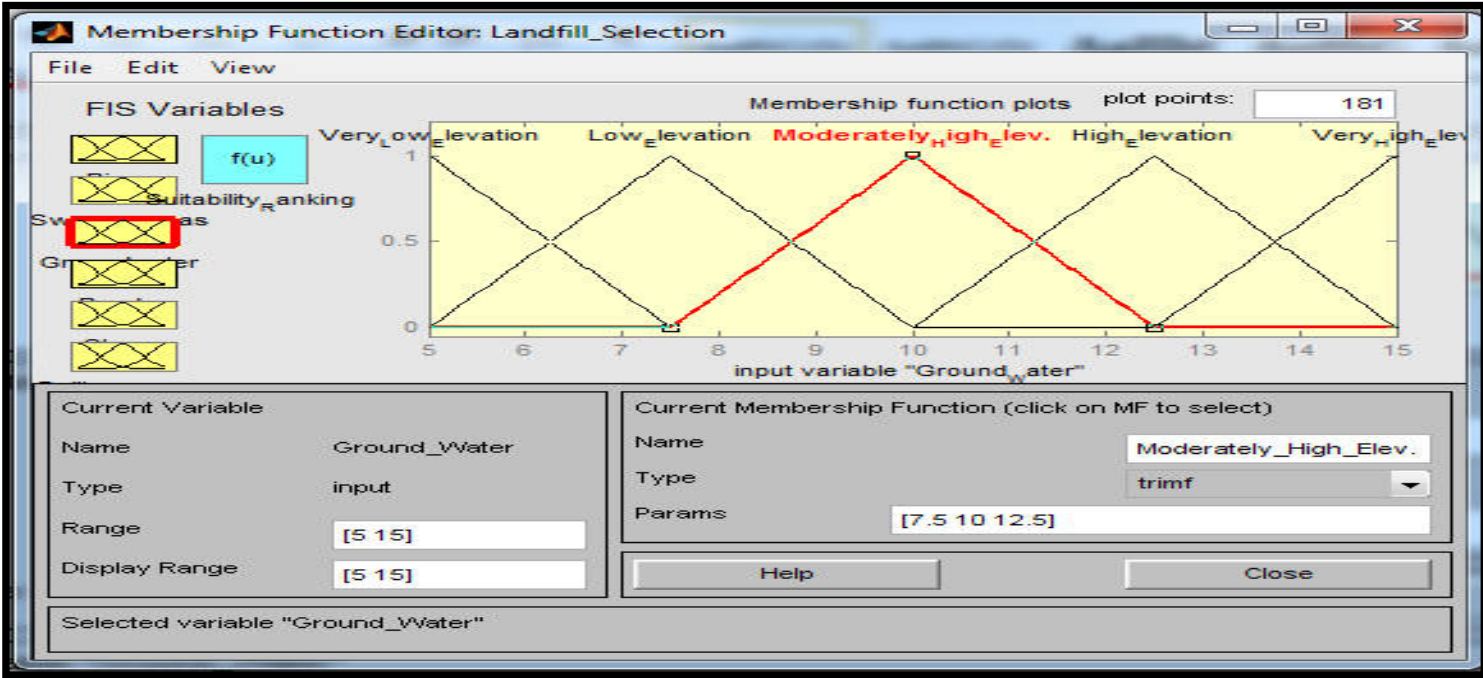

Figure 6b: Definition of membership function for ground water elevation (moderately high elevation)

Figure $6 \mathrm{~b}$ shows the membership function for ground water elevation. The range for ground water elevation is specified as [5 to $15 \mathrm{~m}]$ while the membership set that defines moderately high ground water elevation is given as $[7.5 \mathrm{~m}, 10 \mathrm{~m}, 12.5 \mathrm{~m}]$. The membership function type is the triangular membership function.

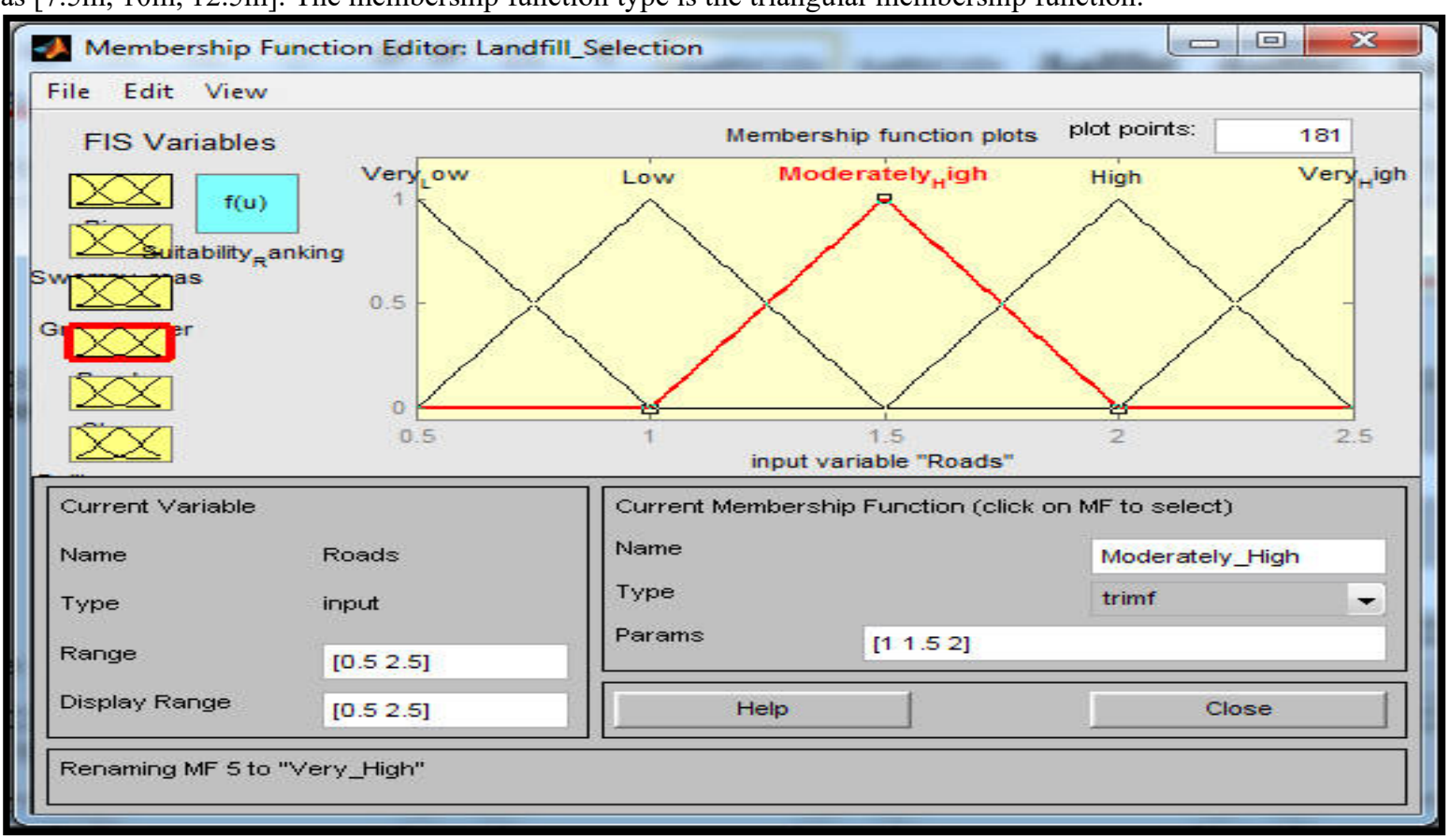

Figure 6c: Definition of membership function for roads (moderately high)

Figure $6 \mathrm{c}$ shows the membership function for road. The range for road buffer distance is specified as $[0.5 \mathrm{~km}$ to $2.5 \mathrm{~km}$ ] while the membership set that defines moderately high buffer distance for roads is given as $[1.0 \mathrm{~km}$, $1.5 \mathrm{~km}, 2.0 \mathrm{~km}]$. The membership function type is the triangular membership function. 


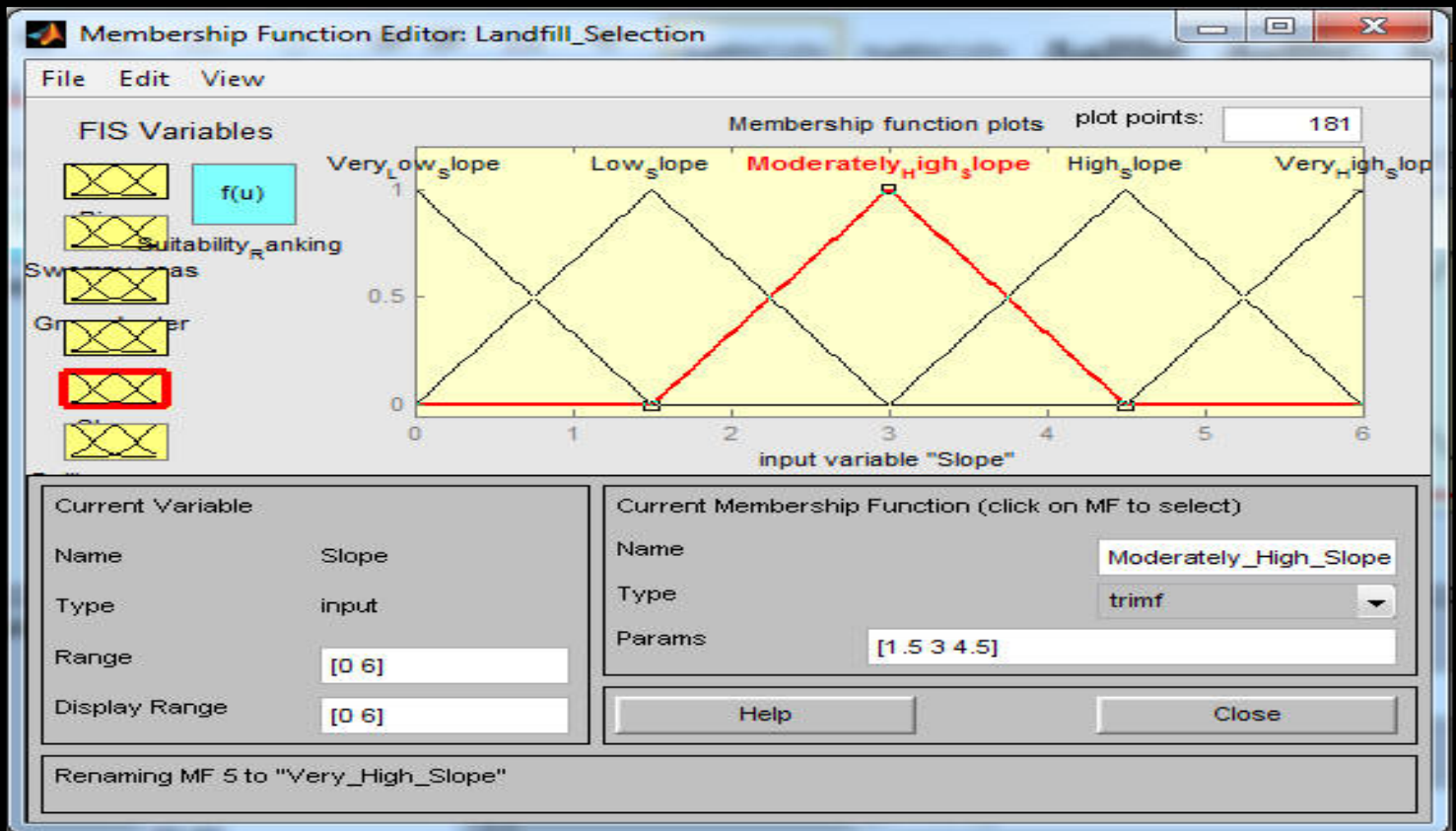

Figure 6d: Definition of membership function for slope (moderately high slope)

Figure $6 \mathrm{~d}$ shows the membership function for slope. The range for slope is specified as $\left[0\right.$ to $\left.6^{0}\right]$ while the membership set that defines moderately high slope is given as $\left[1.5^{0}, 3^{0}, 4.5^{0}\right]$. The membership function type is the triangular membership function.

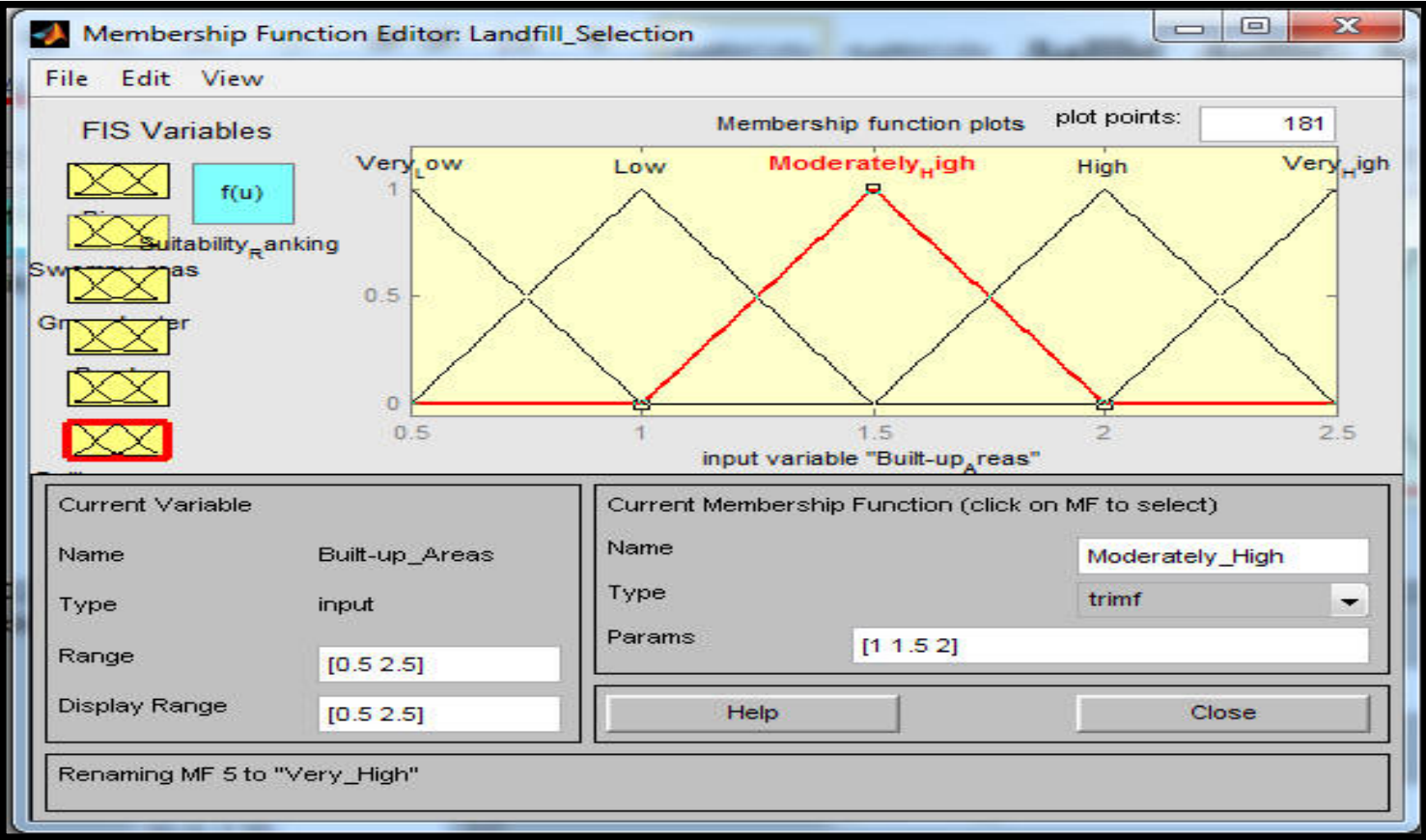

Figure 6e: Definition of membership function for built-up areas (moderately high)

Figure 6e shows the membership function for built-up areas. The range for built-up areas buffer distance is specified as [0.5km to $2.5 \mathrm{~km}]$ while the membership set that defines moderately high buffer distance for built-up areas is given as $[1.0 \mathrm{~km} .1 .5 \mathrm{~km}, 2.0 \mathrm{~km}]$. The membership function type is the triangular membership function. 


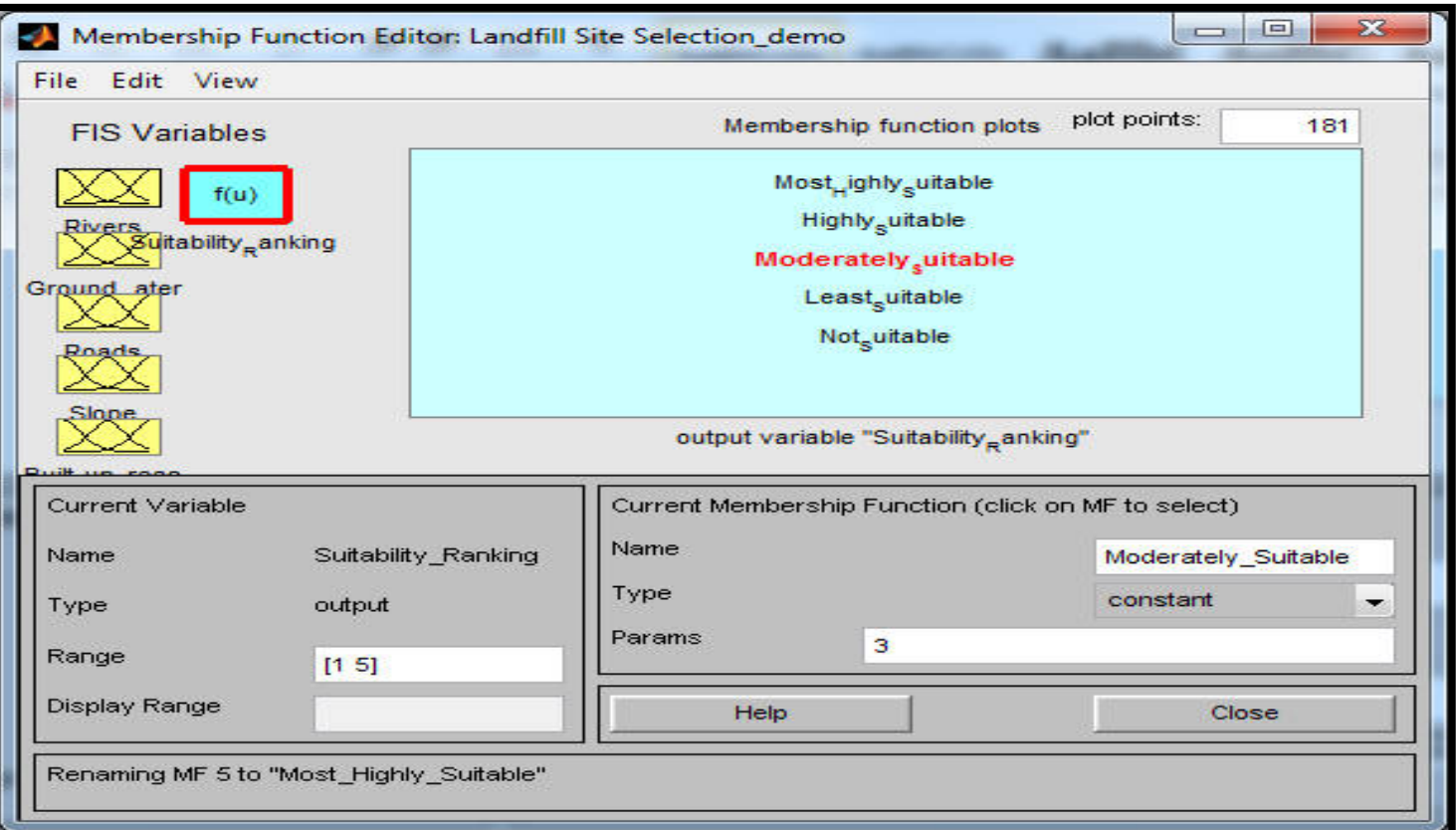

Figure 6f: Definition of membership function for Suitability Ranking (MS)

Figure $6 \mathrm{f}$ shows the membership function for suitability ranking. The range for suitability ranking is specified as [1 to 5] while the membership set that defines moderately suitable is given as [3]. The membership function type is the constant membership function.

\subsection{Predicting the Suitability of Landfill Site using Fuzzy Logic}

Using the rules outlined in section 2.3.5, fuzzy prediction of landfill site selection was done using fuzzy and some of the results obtained are presented in Figures $7 \mathrm{a}, 7 \mathrm{~b}$, and $7 \mathrm{c}$.

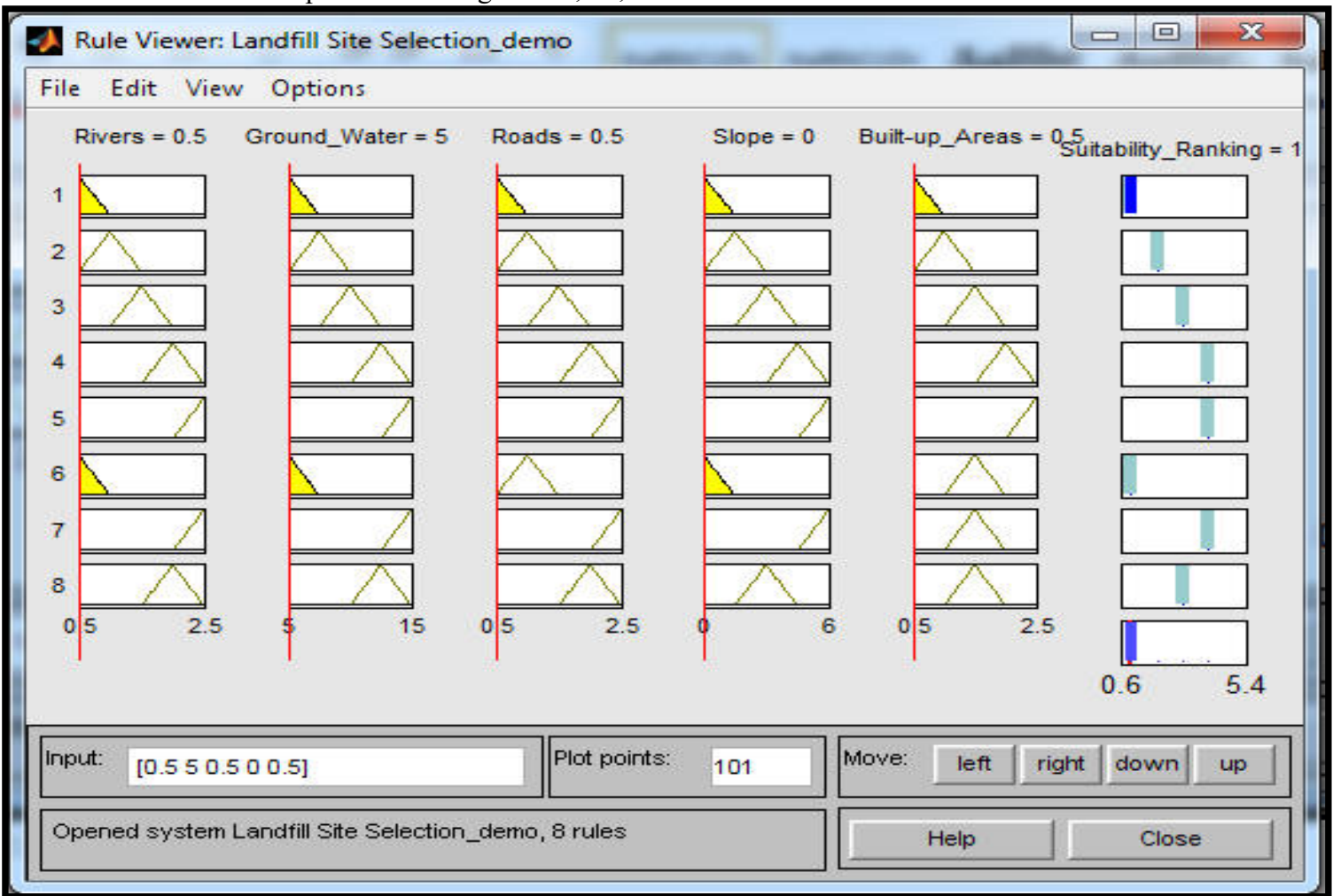

Figure 7a: Predicting suitability of landfill site using fuzzy logic 


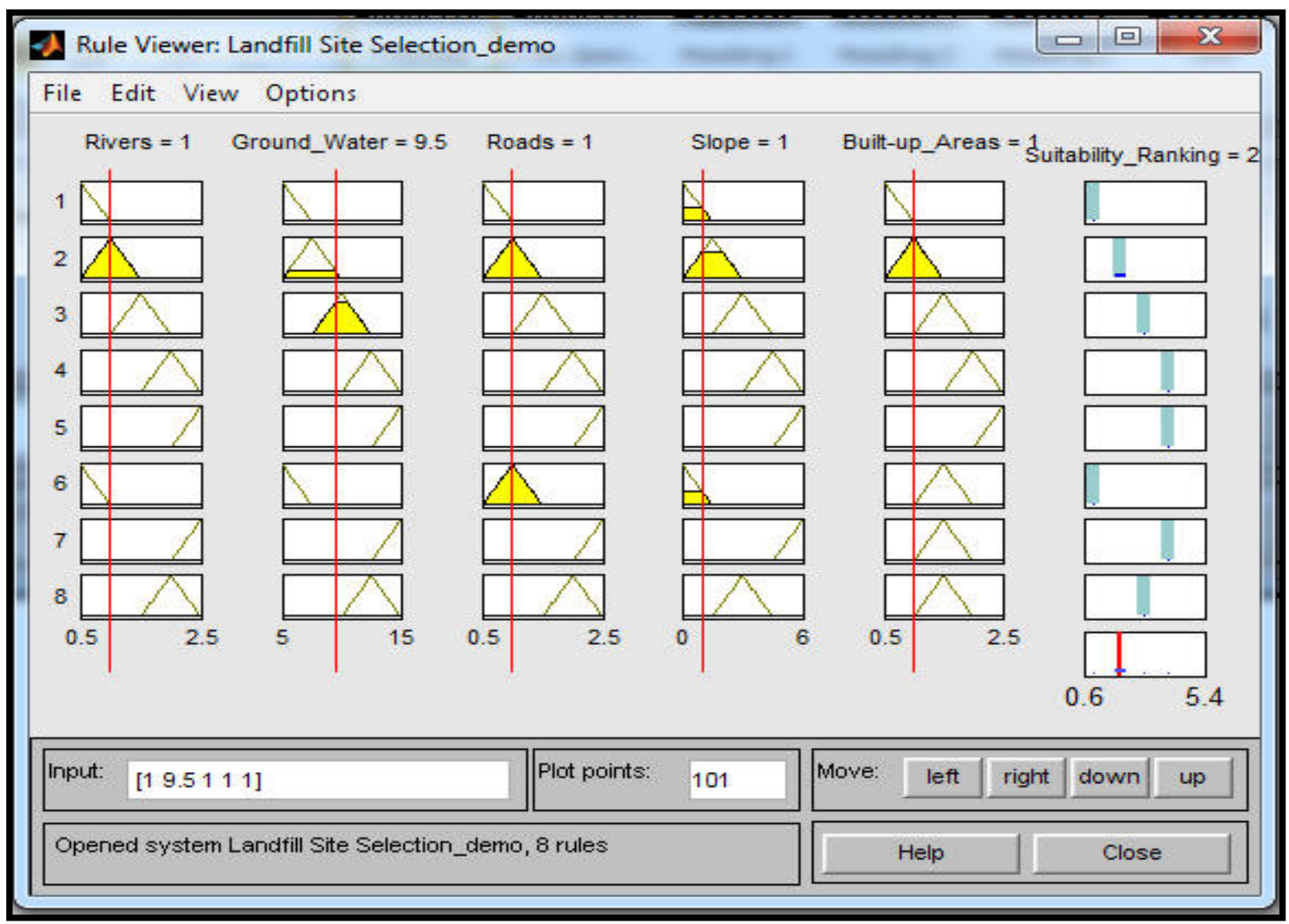

Figure 7b: Predicting suitability of landfill site using fuzzy logic

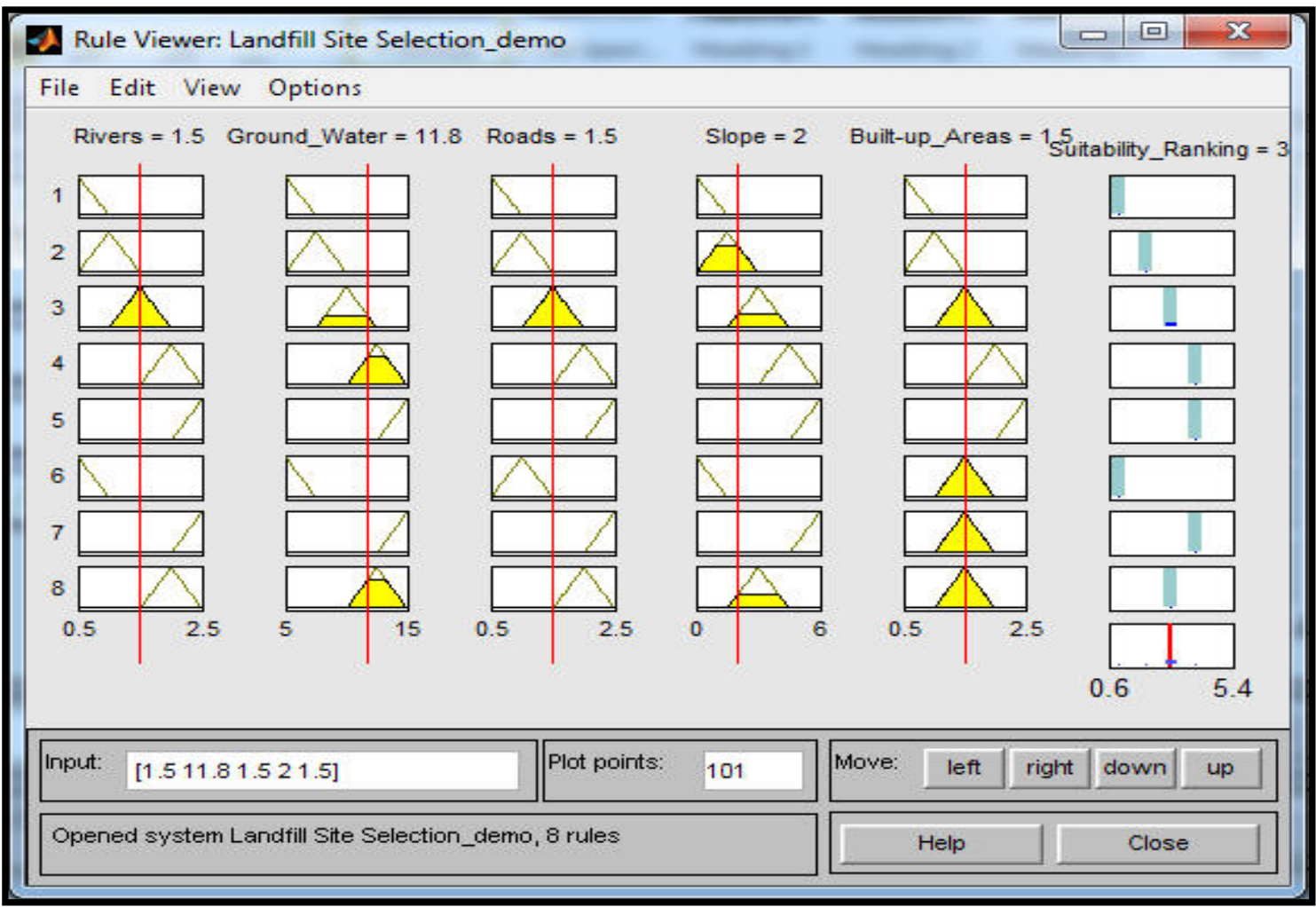

Figure 7c: Predicting suitability of landfill site using fuzzy logic 
From the result of Figure $7 \mathrm{a}$, it was observed that; for river buffer distance of $0.5 \mathrm{~km}$, ground water elevation of $5 \mathrm{~m}$, road buffer distance of $0.5 \mathrm{~km}$, land slope of $0^{0}$ and built-up area buffer distance of $0.5 \mathrm{~km}$, suitability ranking is 1 which means not suitable. From the result of Figure 7b, it was observed that; for river buffer distance of $1.0 \mathrm{~km}$, ground water elevation of $9.5 \mathrm{~m}$, road buffer distance of $1.0 \mathrm{~km}$, land slope of $1^{0}$ and built-up area buffer distance of $1.0 \mathrm{~km}$, suitability ranking is 2 which means least suitable. From the result of Figure $7 \mathrm{c}$, it was observed that; for river buffer distance of $1.5 \mathrm{~km}$, ground water elevation of $11.8 \mathrm{~m}$, road buffer distance of $1.5 \mathrm{~km}$, land slope of $2^{0}$ and built-up area buffer distance of $1.5 \mathrm{~km}$, suitability ranking is 3 which means moderately suitable.

From the results of other simulations, it was observed that for river buffer distance of $1.355 \mathrm{~km}$, ground water elevation of $9.537 \mathrm{~m}$, road buffer distance of $1.645 \mathrm{~km}$, land slope of $3.655^{\circ}$ and built-up area buffer distance of $1.778 \mathrm{~km}$, suitability ranking was 3 which means moderately suitable. For river buffer distance of $0.9909 \mathrm{~km}$, ground water elevation of $7.13 \mathrm{~m}$, road buffer distance of $0.7727 \mathrm{~km}$, land slope of $2.673^{0}$ and built-up area buffer distance of $1.37 \mathrm{~km}$, suitability ranking was 2 which means least suitable. For river buffer distance of $1.5 \mathrm{~km}$, ground water elevation of $10 \mathrm{~m}$, road buffer distance of $1.5 \mathrm{~km}$, land slope of $3^{0}$ and built-up area buffer distance of $1.5 \mathrm{~km}$, suitability ranking was 3 which means moderately suitable.

\section{Conclusion}

The fuzzy logic prediction platform developed in this study can serve as suitable alternative to the popular but complex remote sensing technique in evaluating the suitability of a particular site for sanitary landfill application. It is recommended that the general public should be involved in the selection process for suitable landfill site from the onset, through dissemination of information, consultation and public meetings. Only then will public approval of the site selection process be unbiased, and the final selection be accepted.

\section{References}

1. World Bank (2013); Sanitary Landfill Siting and Design Guidance, Guidance Published in May 1996 by the World Bank as an Urban Infrastructure Note updated November, Washington.

2. Saaty, T.L (2008); Relative measurement and its generalization in decision making; why pairwise comparisons are central in mathematics for the measurement of intangible factors the analytic hierarchy/network process, Rev. R. Acad. Cien. Serie A. Mat. (RACSAM). Stat. Oper. Res. Survey 102 (2), 251-318.

3. Sirigiri, P., Gangadhar, P.V and Kajal, K.G (2012); Evaluation of teacher's performance using Fuzzy Logic Techniques, International Journal of Computer Trends and Technology, vol. 3(2), 200-210

4. Tajuddin, I (2003); Solid Waste Management Strategy in Katsina Metropolis: A case study of Katsina Local Government Area. An unpublished undergraduate research project Department of Geography, Bayero University, Kano

5. Sha'Ato, R., Aboho, S.Y, Oketunde, F.O, Eneji, I.S, Unazi, G and Agwa, S (2007); Survey of solid waste generation and composition in a rapidly growing urban area in central Nigeria. Waste Manage. 27: 352-358

6. Unahabhokha, C., Platts, K. and Hua Tan, K (2007); Predictive performance measurement system: A fuzzy expert system approach, Benchmarking, An International Journal, vol. 14(1), 77-79.

7. Zadeh, L.A (1976); Fuzzy set as a basis for theory of possibility; Fuzzy Sets Systems, vol. 1(2), 3-28. DOI: 10.1016/0165-0114(78)90029-5.

8. Moeinaddini, M, Khorasani, N, Danehkar, A, Darvishsefat, A.A and Zienelyan, M., (2010); Siting MSW landfill using weighted linear combination and analytical hierarchy process (AHP) methodology in GIS Environment (case study: Karaj). Waste Management 30, 912-920 MTA (The General Directorate of Mineral Research and Exploration), Northern Cyprus sheet of the 1:25000-scale Geology Map Report

9. Nas, B., Cay, T., Iscan, F., (2008); Selection of MSW landfill site for Konya, Turkey using GIS and multicriteria evaluation, Environ Monit. Assess, vol. 160, 491-500

10. Guiqin, W., Li, Q., Guoxue, L., Lijun, C., (2009); Landfill site selection using spatial information technologies and AHP: A case study in Beijing, China. Journal of Environmental Management, 1-8

11. Gemitzi, A., Tsihrintzis, V.A, Voudrias, E., (2007); Combining geographic information system, multi-criteria evaluation techniques; and fuzzy logic in siting MSW landfills, Environment Geology 51: 797-811.

12. Akbari, V., Rajabi, M.A., Chavoshi, S.H., Shams, R., (2008); Landfill site selection by combining GIS and fuzzy multi criteria decision analysis, case study: Bandar Abbas, Iran. World Applied Sciences Journal 3, 3947.

13. Davidson, G., (2011), Waste management practices, literature review; Journal of Emerging Trends in Engineering and Applied Science, 1(5), 237-245

14. Egun, N.K (2011); Environmental Responsibility: Nigerians How Far? Journal of Applied Technology in Environmental Sanitation.1 (2): 143 - 147. 